medRxiv preprint doi: https://doi.org/10.1101/2021.06.28.21259644; this version posted November 5, 2021. The copyright holder for this preprint (which was not certified by peer review) is the author/funder, who has granted medRxiv a license to display the preprint in perpetuity.

It is made available under a CC-BY-NC-ND 4.0 International license .

\title{
Title
}

\section{The Role of CRP, Interleukin-6 and Their Derived Immune-Inflammatory Indices in Early Prediction of Severity and Mortality of COVID-19 Patients}

\section{Abstract:}

Running title: CRP, IL-6 and their indices in COVID-19

Background: In coronavirus disease 2019 (COVID-19), finding sensitive biomarkers is critical for detecting severe cases early and intervening effectively. Objectives: To compare and evaluate the predictive value of C-reactive protein (CRP), interleukin-6 (IL-6), and their derived immune-inflammatory indices (CRP/albumin (CRP/alb), lymphocyte/CRP (L/CRP), and lymphocyte/IL-6 (L/IL-6)) in COVID-19 patients. Methods: On admission, 85 confirmed COVID-19 patients, their measured and collected laboratory data were obtained and compared. Results: Levels of CRP, IL-6, and CRP/alb were significantly higher $(\mathrm{P}=0.001)$ in severe patients and non-survivors, but L/CRP and L/IL-6 were significantly lower $(\mathrm{P}=0.001)$. We observed the best predictive performance for COVID-19 severity at 1.65 for CRP/alb and 260.86 for L/CRP with $84.7 \%$ diagnostic accuracy for both. The best diagnostic accuracy for COVID-19 in-hospital mortality was $87.1 \%$ by IL-6 at $120 \mathrm{pg} / \mathrm{ml}$ and $85.9 \%$ by L/IL-6 at 5.40 . The multimarker prediction surpassed the performance of a single biomarker prediction. IL-6 was an independent risk factor associated with severe disease development (odds ratio (OR): 1.033; 95\% confidence interval (CI): 1.002-1.066). Conclusions: Pretreatment values of CRP, IL-6, and their derived indices could be included in the diagnostic work-up of COVID-19 to determine the severity and predict the outcome.

Keywords: COVID-19; CRP; Interleukin-6; Mortality; Ratio; Severity 


\section{Introduction:}

The pandemic of coronavirus disease 2019 (COVID-19) is presently sweeping the globe, affecting millions of individuals. ${ }^{1}$ COVID-19 is more contagious than seasonal influenza, has a longer incubation time, and is linked to a greater hospitalization rate and overall mortality. The virus spreads through the respiratory tract and quickly progresses to severe infection, multi-organ failure, and even death. ${ }^{2}$

Although most COVID-19 patients recover quickly, patients with moderate severity, particularly those with risk factors like old age, obesity, and associated co-morbidities, can rapidly worsen and become severe, increasing ICU admission and mechanical ventilation, indicating a high mortality rate. ${ }^{3}$ Thus, early identification of potentially severe patients is critical for halting disease progression at an early stage.

COVID-19 progression may be facilitated by an abnormal inflammatory response and cytokine storm. $^{4}$ Therefore, this study was performed to evaluate the predictive efficacy of individual and combined baseline inflammatory indicators; C-reactive protein (CRP) and interleukin-6 (IL-6) together with their derived immune-inflammatory indices (CRP/albumin (CRP/alb), lymphocyte/CRP (L/CRP), and lymphocyte/IL-6 (L/IL-6)) in a cohort of Egyptian COVID-19 patients.

\section{Materials \& methods:}

\section{Patients:}

This cohort observational study recruited 85 adult patients (aged $\geq 18$ years) from COVID-19 Isolation Hospitals of Ain-Shams University, Cairo, Egypt. A real-time polymerase chain reaction (RT-PCR) test confirmed COVID-19 in all of the patients. We excluded pregnant women and patients with any hematological diseases, immunodeficiencies, or autoimmune 
disorders. All participants were classified according to their disease severity using the COVID19 management guideline provided by Ain Shams University Hospitals. ${ }^{5}$

\section{Data collection:}

From medical records, epidemiological and clinical data (such as age, sex, underlying diseases or comorbidities, length of stay in the hospital, the requirement for ICU admission, and patients' outcomes) were collected, as well as laboratory findings from the same day (such as complete blood differential counts and CRP).

\section{Blood sampling and analysis:}

Venous blood samples were taken via venipuncture from all enrolled patients into biochemistry tubes covered with gel for serum separation. The samples were allowed to clot for 30 mins before being centrifuged for 10 mins at 2,500 g. The serum was immediately used to determine albumin level using a Beckman Coulter AU480 autoanalyzer (Beckman Coulter, Inc., USA). The dynamic range of albumin was 1.5-6.0 $\mathrm{g} / \mathrm{dL}$. The remaining sera were kept at $-80^{\circ} \mathrm{C}$ until they were tested for IL-6 using a commercially available Human IL-6 ELISA Kit from RayBiotech Life, Inc., GA, USA [CODE: ELH-IL6-1]. According to the supplier's instructions, the assay was carried out with a detection range of $3 \mathrm{pg} / \mathrm{ml}-1000 \mathrm{pg} / \mathrm{ml}$.

\section{Calculations:}

Derived immune-inflammatory indices were calculated as follows: L/CRP = lymphocyte $($ number/ $\mu \mathrm{l}) / \mathrm{CRP}(\mathrm{mg} / \mathrm{dl}) ; \mathrm{L} / \mathrm{IL}-6=$ lymphocyte $($ number/ $\mu \mathrm{l}) / \mathrm{IL}-6(\mathrm{pg} / \mathrm{ml}) ; \mathrm{CRP} / \mathrm{alb}=\mathrm{CRP}$ $(\mathrm{mg} / \mathrm{dl}) /$ albumin $(\mathrm{g} / \mathrm{dl})$.

\section{Statistical analysis:}

Statistical analysis was performed using the SPSS 20.0. Descriptive statistics were done using median and percentiles for quantitative nonparametric measures, while categorized data were described in numbers and percentages. The Wilcoxon Rank Sum test and Chi-square test were 
used to compare two groups of quantitative nonparametric and qualitative data, respectively. The receiver operating characteristic (ROC) curve assessed the predictive performance of each pretreatment biomarker alone and the clinical benefit of the biomarkers combination. The odds ratio $(\mathrm{OR})$ and $95 \%$ confidence interval $(\mathrm{CI})$ were calculated using logistic regression analysis. The significant probability of error was set at 0.05 .

\section{Results:}

\section{Demographic and Clinical Characterization of the Study Cohort}

Of the 85 included patients, 48 (56.5\%) were males, and 37 (43.5\%) were females with a median (IQR) age of 55 years $(42-65)$. Of all, 54.1\% $(n=46)$ were non-severe while $45.9 \%(n=39)$ were severe. The most prevalent presenting symptoms were dyspnea (51.8\%) and fever (40\%). Hypertension (40.0\%) and diabetes mellitus (36.5\%) were the most common associated comorbidities. The median (IQR) duration of hospitalization was 10 days (6 - 17), during which $38.8 \%(n=33)$ of patients required ICU admission, and $24.7 \%(n=21)$ died. Baseline findings of the studied population $(\mathrm{n}=85)$ are demonstrated in table $\mathbf{1}$.

\section{Characteristics of COVID-19 patients according to disease severity and in-hospital mortality:}

Table 2 compares the baseline clinical characteristics and laboratory findings according to the severity and in-hospital mortality of COVID-19 patients.

Significant changes between the severity groups were observed when their median (IQR) values were compared. As opposed to the non-severe group, severe patients had significantly higher values of CRP (129 (IQR: 50 - 152) vs.12 (6.5 - 32) mg/L; P $\leq 0.001)$, IL-6 (120 (80 - 220) vs. $32(18-50) \mathrm{pg} / \mathrm{ml} ; \mathrm{P} \leq 0.001)$ and CRP/alb (3.87 (1.66 - 4.90) vs. 0.35 (0.15 - 0.64); $\mathrm{P} \leq$ 0.001). And, significantly lower values of L/CRP (105.26 (56.96 - 230.26) vs. 1211.96 (449.82 2500); $\mathrm{P} \leq 0.001)$, L/IL-6 (8.33 (4.20 - 14.54) vs. 40.83 (25.20 - 98.71); $\mathrm{P} \leq 0.001)$, lymphocyte 
count $(0.9(0.5-2.2)$ vs.1.49 $(1-2.22) \times 103 / \mu \mathrm{L} ; \mathrm{P}=0.028)$ and albumin $(3.2(2.9-3.6)$ vs. 4 $(3.1-4.8) \mathrm{g} / \mathrm{dl} ; \mathrm{P} \leq 0.001)$

Regarding in-hospital mortality of COVID-19, significant differences between survivors and non-survivors were observed. CRP (152 (57.8 - 152) vs.18 (7.7 - 65.75) mg/L;P $\leq 0.001)$, IL-6 (168 (110 - 275) vs. 45 (20 - 97.5) pg/ml; P $\leq 0.001)$, and CRP/alb (4.3 (1.82 - 5.52) vs. 0.52 $(0.20-1.70) ; \mathrm{P} \leq 0.001)$ showed significantly higher values in non-survivors compared to survivors. In contrast, L/CRP (105.26 (43.56 - 212.5) vs. 703.27 (186.18 - 2005.35); P $\leq 0.001)$, L/IL-6 (5.33 (3.34 - 14.55) vs. $29.55(11.90-79) ; \mathrm{P} \leq 0.001)$ and albumin (3 (2.75 - 3.6) vs. $3.75(3.02-4.35) \mathrm{g} / \mathrm{dl} ; \mathrm{P}=0.001)$ were significantly lower. But, the change in lymphocyte count according to in-hospital mortality was not significant $(0.9(0.55-1.96)$ vs.1.4 (0.77 - 2.2) $\times 103 / \mu \mathrm{L} ; \mathrm{P}=0.178)$.

\section{Predictive performance evaluation:}

Table 3: shows diagnostic validity tests and ROC curve analysis used to assess each biomarker's overall prognostic performance on its own, identifying those that performed well. Biomarkers with the best diagnostic efficacies (least false and highest true results) were then combined in a multi-ROC curve to maximize the AUC and improve predictive accuracy.

Regarding COVID-19 severity, while CRP alone at a cut-off of $48 \mathrm{mg} / \mathrm{L}$ offered 0.861 AUC and 82.4\% diagnostic accuracy, its derived indices, CRP/alb, and L/CRP, exhibited the best predictive performance compared to other biomarkers. At the cut-off point of 1.65 for CRP/alb and 260.86 for L/CRP, the AUC was 0.878 and 0.873 , respectively, and the diagnostic accuracy was $84.7 \%$ for both. And when CRP/alb at a cut-off point of 1.65 was combined with L/CRP at a cut-off point of 2300 in a multi-ROC analysis, COVID-19 severity prediction accuracy increased to $95.3 \%$ with an AUC of 0.922 . Figure 1 
Concerning COVID-19 in-hospital mortality, the baseline IL-6 level was the most highly predictive biomarker with 0.88 AUC at a cut-off point of $120 \mathrm{pg} / \mathrm{ml}$ and diagnostic accuracy of 87.1\%. Comparable to IL-6 was L/IL-6 with 0.86 AUC at a cut-off point of 5.40 and a diagnostic accuracy of $85.9 \%$. Adding IL-6 at a cut-off point of $120 \mathrm{pg} / \mathrm{ml}$ to L/IL-6 at a cut-off point of 8 has improved the overall in-hospital mortality prediction ability and increased the AUC to 0.946 and the diagnostic accuracy to $96.5 \%$. Figure 2

\section{Risk factors assessment:}

Logistic regression analysis further evaluated the association between IL-6, CRP, and their derived indices with COVID-19 severity and in-hospital mortality. As to COVID-19 in-hospital mortality, the multivariate analysis showed that the odds ratios (ORs) of all studied biomarkers were not significantly different $(\mathrm{p}>0.05)$. And only IL-6 was an independent risk that was significantly positively associated with severe disease development (OR: 1.033; 95\% CI: 1.002 1.066; $\mathrm{P}=0.037$ ). Table 4 demonstrates logistic regression analysis for possible predictors of COVID-19 severity and in-hospital mortality.

\section{Discussion:}

During the current pandemic of COVID-19, since immune dysfunction, hyper-inflammation, and hyper-cytokinaemia have been closely linked to the rapid progression of the disease ${ }^{\mathbf{6}}{ }^{\text {continuous }}$ finding of sensitive inflammatory biomarkers for timely and effective identification of disease progression is necessary. $^{7}$

CRP, an inflammatory molecule that plays a vital role in host resistance to infections, was highly linked to acute lung injury and unfavorable outcomes in COVID-19 patients. As a result, detecting CRP levels is quite useful in determining the severity of COVID-19 patients. ${ }^{\mathbf{8}}$

In our study, CRP increased significantly with COVID-19 severity and mortality. Similarly, several studies have reported significantly higher CRP values in the more severe patients and 
those who died from the disease. ${ }^{8-10}$ On the contrary, Zhang Y. revealed no significant change in CRP levels in patients after being admitted to ICU. ${ }^{11}$ Also, Ferrari and colleagues, based on statistical analysis, stated that CRP might not be very useful in discriminating between patients with or without COVID-19. ${ }^{12}$

IL-6 is a multifunctional cytokine that regulates immunological and inflammatory responses. It plays a key role in the development and progression of coronavirus pneumonia. In COVID-19 patients with the hyper-inflammatory syndrome, circulating IL-6 concentrations have been linked to disease severity, the incidence of acute lung damage, and mechanical ventilation need, suggesting that measuring IL-6 levels can help guide therapy decisions. ${ }^{\mathbf{1 3}}$

In our study, IL-6 levels were significantly higher in severe patients and non-survivors. Per our results, Sun and co-workers reported significantly higher IL-6 values in the more severe patients. ${ }^{\mathbf{1 3}}$ Also, Coomes and Haghbayan have reported similar results in their systemic review. ${ }^{\mathbf{1 4}}$ Furthermore, several studies have reported the distinct clinical significance of IL-6 at varying cut-off values. Gao et al. studied a cohort of 43 cases and reported that combining IL-6 at a cutoff value of $24.3 \mathrm{pg} / \mathrm{ml}$ with the D-Dimer helped in the early detection of severity progression. $^{15}$ In another cohort by Giofoni et al., serum IL-6 at a cut-off value of $25 \mathrm{pg} / \mathrm{ml}$ represented an independent risk of COVID-19 progression. ${ }^{\mathbf{1 6}}$ In a cohort study of 40 patients in Munich, COVID-19 patients' need for mechanical ventilation increased 22 times with the elevated IL-6 levels (> $80 \mathrm{pg} / \mathrm{ml}){ }^{\mathbf{1 7}}$

In a meta-analysis, Coomes and Haghbayan discovered statistical heterogeneity in IL6 levels in subjects with varying degrees of disease severity. They attributed this to inconsistencies of patients' characteristics in each trial and discrepancies in the timing of IL6 testing and immunomodulatory medicines received. ${ }^{\mathbf{1 4}}$ 
Significant hypo-albuminemia and lymphopenia were discovered in severe patients in the current study; however, only significant hypo-albuminemia and not lymphopenia was detected in nonsurvivors. Returning to the fact that albumin levels drop in inflammatory conditions, hypoalbuminemia has been noted in COVID-19 patients with severe hyperinflammation. ${ }^{\mathbf{1 8}}$

In several studies, ${ }^{3,19}$ COVID-19 severity and progression have been linked to lymphopenia, a reliable and accurate prediction. According to a meta-analysis study, the more serious the condition, the fewer lymphocytes there were ${ }^{\mathbf{2 0}}$, which could be attributed to the disease's effect on $\mathrm{T}$ cell subsets, resulting in immunological dysfunction. ${ }^{\mathbf{2 1 , 2 2}}$ Several studies have emphasized that when the lymphocyte count is less than $1.510^{3} / \mu \mathrm{L}$, lymphopenia should be addressed. ${ }^{9}$

Using an inflammatory biomarker alone to evaluate patients infected with COVID-19 could be influenced by several factors. As a result, the generated indices from the most important inflammatory biomarkers may more accurately and thoroughly indicate immunological dysregulation. ${ }^{7,23}$

For numerous malignancies, including colon and stomach carcinomas, the L/CRP has been employed as a prognostic marker because it's a good predictor of the complicated host-tumor immunological interactions that lead to the systemic inflammatory process implicated in the etiology of these carcinomas. ${ }^{\mathbf{2 4 - 2 6}}$ COVID-19 also triggers an inflammatory reaction throughout the body; therefore, the L/CRP could be a useful prognostic biomarker for disease severity and outcome. On exploring the role of L/CRP in the prognosis of our studied COVID-19 patients, we found that it declined significantly with the increase in disease severity and mortality. By our results, Ullah and co-workers have found that a low L/CRP was a good predictor of complications and mortality in COVID-19 patients. ${ }^{24}$

High CRP/alb was previously linked to mortality in critically ill patients of various conditions. ${ }^{27}$ In our study, we found a significant elevation of the CRP/alb as the disease 
progressed. Similarly, El-Shabrawy and colleagues have found that the CRP/alb was a predictive factor of COVID-19 mortality. ${ }^{28}$

In our study, the L/IL-6 was much lower in severe COVID-19 patients and non-survivors. In the same context, because high IL-6 levels and low lymphocyte counts have been connected to the severity and in-hospital mortality of COVID-19, in a study by Yang and colleagues, the IL6/lymphocyte ratio (IL-6/L, reversed) was described as a novel biomarker to conduct risk stratification in COVID-19 patients. ${ }^{7}$ Other studies have found that having a high IL-6/L is an independent risk factor for disease progression and a poor prognosis. ${ }^{\mathbf{2 9}, \mathbf{3 0}}$ The decrease in lymphocyte numbers caused by IL-6-mediated inhibition of T cell activation explained the high in COVID-19. ${ }^{31}$ Furthermore, in a study by Liu et al., T cell numbers were inversely associated with the studied cytokine levels, including $\mathrm{IL}-6 .{ }^{32}$ As a result, the balance of IL-6 and lymphocytes appeared to be crucial in the immune system's homeostasis.

In the multi-ROC curve analysis, we integrated biomarkers that exhibited the best predictive performance for COVID-19 progression to achieve the maximum overall test efficacy and improve the predictive ability. The combination of CRP/alb and L/CRP improved disease severity prediction accuracy. Similarly, combining IL-6 with the L/IL-6 enhanced in-hospital mortality prediction accuracy. Finally, only IL-6 was positively correlated with disease severity, but none of the investigated biomarkers were shown to be an independent predictor of in-hospital mortality. This could be attributed to the small sample size and the disproportion between the study groups, and these were the study's major limitations.

More research on a larger scale and for a longer period is needed to determine the predictive usefulness of the proposed inflammatory indices compared to the other existing biomarkers to slow the disease's progression and put the epidemic to an end.

\section{Conclusions:}


The current study discovered that CRP and IL-6 and their derived immune-inflammatory indices, namely CRP/alb, L/CRP, and L/IL-6, were good predictors of COVID-19 progression. Using these indicators in combinations rather than a single biomarker alone would improve the overall performance in disease progression prediction.

\section{Abbreviations:}

CRP/alb: CRP/albumin; L/CRP: lymphocyte/CRP; L/IL-6: lymphocyte/IL-6

Acknowledgement: None.

\section{Authors' contribution:}

All authors contributed significantly to this work, whether it was in the conception, study design, data acquisition, analysis, and interpretation, or in the drafting, revising, or reviewing of the article, and they all provided final approval of the version to be published.

Data availability statement: On reasonable request, the corresponding author will provide the datasets used and/or analyzed during the current work.

Conflicts of interest disclosure: The author(s) declared no potential conflicts of interest.

Funding sources: This research did not receive any specific grant from funding agencies in the public, commercial, or not-for-profit sectors.

Ethics: Ethical approval for the current study protocol was obtained from Ain Shams University Faculty of Medicine Research Ethics Committee (REC) FWA 00017585. All patient data were kept private and confidential. Solely utilized them for research purposes.

Statement of informed consent: All procedures were explained to all participants or their firstdegree relatives, with informed consent obtained from them.

Consent for publication: Not applicable.

\section{References:}


1. Chan AS, Rout A. Use of Neutrophil-to-Lymphocyte and Platelet-to-Lymphocyte Ratios in COVID-19. J Clin Med Res. 2020 Jul;12(7):448-453. doi: 10.14740/jocmr4240. Epub 2020 Jun 25. PMID: 32655740; PMCID: PMC7331861.

2. Feng X, Li S, Sun Q, et al. Immune-Inflammatory Parameters in COVID-19 Cases: A Systematic Review and Meta-Analysis. Front Med (Lausanne). [online] 2020;7:301. Available at: https://www.ncbi.nlm.nih.gov/pmc/articles/PMC7295898/pdf/fmed-0700301.pdf [Accessed 9 Jan. 2021].

3. Tan L, Wang Q, Zhang D, Ding J, Huang Q, Tang YQ, et al. Lymphopenia predicts disease severity of COVID-19: a descriptive and predictive study. Signal Transduct Target Ther. 2020 Mar 27;5(1):33. doi: 10.1038/s41392-020-0148-4. Erratum in: Signal Transduct Target Ther. 2020 Apr 29;5(1):61. PMID: 32296069; PMCID: PMC7100419.

4. Zhu Z, Cai T, Fan L, Lou K, Hua X, Huang Z, et al. Clinical value of immuneinflammatory parameters to assess the severity of coronavirus disease 2019. Int J Infect Dis. 2020 Jun;95:332-339. doi: 10.1016/j.ijid.2020.04.041. Epub 2020 Apr 22. PMID: 32334118; PMCID: PMC7195003.

5. Badawy Abdelfattah E, Ahmed El-Zahapy H, El Said A, et al. Hospital response to COVID-19 a consensus: Report on Ain Shams University Hospital Strategy. ScienceOpen. 2020 [online] [Accessed 9 Feb. 2021].

6. Mehta P, McAuley DF, Brown M, Sanchez E, Tattersall RS, Manson JJ et al. COVID-19: consider cytokine storm syndromes and immunosuppression. Lancet. 2020 Mar 28;395(10229):1033-1034. doi: 10.1016/S0140-6736(20)30628-0. Epub 2020 Mar 16. PMID: 32192578; PMCID: PMC7270045.

7. Yang B, Chang X, Huang J, Pan W, Si Z, Zhang C, et al. The role of IL-6/lymphocyte ratio in the peripheral blood of severe patients with COVID-19. Int Immunopharmacol. 
2021 Aug;97:107569. doi: 10.1016/j.intimp.2021.107569. Epub 2021 Mar 12. PMID: 33933851; PMCID: PMC7953449.

8. Shang W, Dong J, Ren Y, Tian M, Li W, Hu J, et al. The value of clinical parameters in predicting the severity of COVID-19. J Med Virol. 2020 Oct;92(10):2188-2192. doi: 10.1002/jmv.26031. Epub 2020 Jun 2. PMID: 32436996; PMCID: PMC7280691.

9. Kazemi E, Soldoozi Nejat R, Ashkan F, Sheibani H. The laboratory findings and different COVID-19 severities: a systematic review and meta-analysis. Ann Clin Microbiol Antimicrob. 2021 Mar 16;20(1):17. doi: 10.1186/s12941-021-00420-3. PMID: 33726761; PMCID: PMC7962428.

10. Danwang C, Endomba FT, Nkeck JR, Wouna DLA, Robert A, Noubiap JJ. A metaanalysis of potential biomarkers associated with severity of coronavirus disease 2019 (COVID-19). Biomark Res. 2020 Aug 31;8:37. doi: 10.1186/s40364-020-00217-0. PMID: 32879731; PMCID: PMC7456766.

11. Zhang Y, Zheng L, Liu L, Zhao M, Xiao J, Zhao Q. Liver impairment in COVID-19 patients: A retrospective analysis of 115 cases from a single centre in Wuhan city, China. Liver Int. 2020 Sep;40(9):2095-2103. doi: 10.1111/liv.14455. Epub 2020 Apr 28. PMID: 32239796.

12. Ferrari D, Motta A, Strollo M, Banfi G, Locatelli M. Routine blood tests as a potential diagnostic tool for COVID-19. Clin Chem Lab Med. 2020 Jun 25;58(7):1095-1099. doi: 10.1515/cclm-2020-0398. PMID: 32301746.

13. Sun H, Guo P, Zhang L, Wang F. Serum Interleukin-6 Concentrations and the Severity of COVID-19 Pneumonia: A Retrospective Study at a Single Center in Bengbu City, Anhui Province, China, in January and February 2020. Med Sci Monit. 2020 Nov 11;26:e926941. doi: 10.12659/MSM.926941. PMID: 33175722; PMCID: PMC7670831. 
14. Coomes EA, Haghbayan H. Interleukin-6 in Covid-19: A systematic review and metaanalysis. Rev Med Virol. 2020 Nov;30(6):1-9. doi: 10.1002/rmv.2141. Epub 2020 Aug 26. PMID: 32845568; PMCID: PMC7460877.

15. Gao Y, Li T, Han M, et al. Diagnostic utility of clinical laboratory data determinations for patients with the severe COVID-19. J Med Virol. 2020; 92(7):791-796.

16. Grifoni E, Valoriani A, Cei F, Lamanna R, Gelli AMG, Ciambotti B, et al. Interleukin-6 as prognosticator in patients with COVID-19. J Infect. 2020 Sep;81(3):452-482. doi: 10.1016/j.jinf.2020.06.008. Epub 2020 Jun 8. PMID: 32526326; PMCID: PMC7278637.

17. Herold T, Jurinovic V, Arnreich C, et al (2020) Level of IL-6 predicts respiratory failure in hospitalized symptomatic COVID-19 patients. medRxiv (preprint).

18. Aziz M, Fatima R, Lee-Smith W, Assaly R. The association of low serum albumin level with severe COVID-19: a systematic review and meta-analysis. Crit Care. 2020 May 26;24(1):255. doi: 10.1186/s13054-020-02995-3. PMID: 32456658; PMCID: PMC7249975.

19. Terpos E, Ntanasis-Stathopoulos I, Elalamy I, Kastritis E, Sergentanis TN, Politou M, et al. Hematological findings and complications of COVID-19. Am J Hematol. 2020 Jul;95(7):834-847. doi: 10.1002/ajh.25829. Epub 2020 May 23. PMID: 32282949; PMCID: PMC7262337.

20. Pourbagheri-Sigaroodi A, Bashash D, Fateh F, Abolghasemi H. Laboratory findings in COVID-19 diagnosis and prognosis. Clin Chim Acta. 2020 Nov;510:475-482. doi: 10.1016/j.cca.2020.08.019. Epub 2020 Aug 14. PMID: 32798514; PMCID: PMC7426219.

21. Tufan A, Avanoğlu Güler A, Matucci-Cerinic M. COVID-19, immune system response, hyperinflammation and repurposing antirheumatic drugs. Turk J Med Sci. 2020 Apr 
21;50(SI-1):620-632. doi: 10.3906/sag-2004-168. PMID: 32299202; PMCID: PMC7195984.

22. Wang F, Nie J, Wang H, Zhao Q, Xiong Y, Deng L, et al. Characteristics of Peripheral Lymphocyte Subset Alteration in COVID-19 Pneumonia. J Infect Dis. 2020 May 11;221(11):1762-1769. doi: 10.1093/infdis/jiaa150. PMID: 32227123; PMCID: PMC7184346.

23. Sun Y, Dong Y, Wang L, Xie H, Li B, Chang C, et al. Characteristics and prognostic factors of disease severity in patients with COVID-19: The Beijing experience. J Autoimmun. 2020 Aug;112:102473. doi: 10.1016/j.jaut.2020.102473. Epub 2020 Apr 24. PMID: 32439209; PMCID: PMC7180376.

24. Ullah W, Basyal B, Tariq S, Almas T, Saeed R, Roomi S, et al. Lymphocyte-to-CReactive Protein Ratio: A Novel Predictor of Adverse Outcomes in COVID-19. J Clin Med Res. 2020 Jul;12(7):415-422. doi: 10.14740/jocmr4227. Epub 2020 Jun 25. PMID: 32655735; PMCID: PMC7331862.

25. Okugawa Y, Toiyama Y, Yamamoto A, Shigemori T, Ichikawa T, Yin C, et al. Lymphocyte-to-C-reactive protein ratio and score are clinically feasible nutritioninflammation markers of outcome in patients with gastric cancer. Clin Nutr. 2020 Apr;39(4):1209-1217. doi: 10.1016/j.clnu.2019.05.009. Epub 2019 May 21. PMID: 31155370.

26. Okugawa Y, Toiyama Y, Yamamoto A, Shigemori T, Ide S, Kitajima T, et al. Lymphocyte-C-reactive Protein Ratio as Promising New Marker for Predicting Surgical and Oncological Outcomes in Colorectal Cancer. Ann Surg. 2020 Aug;272(2):342-351. doi: 10.1097/SLA.0000000000003239. PMID: 32675548. 
27. Akirov A, Masri-Iraqi H, Atamna A, Shimon I. Corrigendum to 'Low Albumin Levels Are Associated with Mortality Risk in Hospitalized Patients' American Journal of Medicine 2017:130(12):1465.e11-1465.e19. Am J Med. 2020 May;133(5):646. doi: 10.1016/j.amjmed.2020.02.001. Epub 2020 Feb 29. Erratum for: Am J Med. 2017 Dec;130(12):1465.e11-1465.e19. PMID: 32127192.

28. El-Shabrawy M, Alsadik ME, El-Shafei M, et al. Interleukin-6 and C-reactive protein/albumin ratio as predictors of COVID-19 severity and mortality. Egypt $J$ Bronchol. 2021;15(1):5.

29. Chen X, Zhao B, Qu Y, Chen Y, Xiong J, Feng Y, et al. Detectable Serum Severe Acute Respiratory Syndrome Coronavirus 2 Viral Load (RNAemia) Is Closely Correlated With Drastically Elevated Interleukin 6 Level in Critically Ill Patients With Coronavirus Disease 2019. Clin Infect Dis. 2020 Nov 5;71(8):1937-1942. doi: 10.1093/cid/ciaa449. PMID: 32301997; PMCID: PMC7184354.

30. Chiappelli F, Khakshooy A, Greenberg G. CoViD-19 Immunopathology and Immunotherapy. Bioinformation. 2020 Mar 31;16(3):219-222. doi: 10.6026/97320630016219. PMID: 32308263; PMCID: PMC7147500.

31. Guan WJ, Ni ZY, Hu Y, Liang WH, Ou CQ, He JX, et al . Clinical Characteristics of Coronavirus Disease 2019 in China. N Engl J Med. 2020 Apr 30;382(18):1708-1720. doi: 10.1056/NEJMoa2002032. Epub 2020 Feb 28. PMID: 32109013; PMCID: PMC7092819.

32. Liu J, Li S, Liu J, Liang B, Wang X, Wang H, et al. Longitudinal characteristics of lymphocyte responses and cytokine profiles in the peripheral blood of SARS-CoV-2 infected patients. $\quad$ EBioMedicine. 2020 May;55:102763. doi: 10.1016/j.ebiom.2020.102763. Epub 2020 Apr 18. PMID: 32361250; PMCID: 
medRxiv preprint doi: https://doi.org/10.1101/2021.06.28.21259644; this version posted November 5, 2021. The copyright holder for this preprint (which was not certified by peer review) is the author/funder, who has granted medRxiv a license to display the preprint in perpetuity.

It is made available under a CC-BY-NC-ND 4.0 International license .

PMC7165294. 


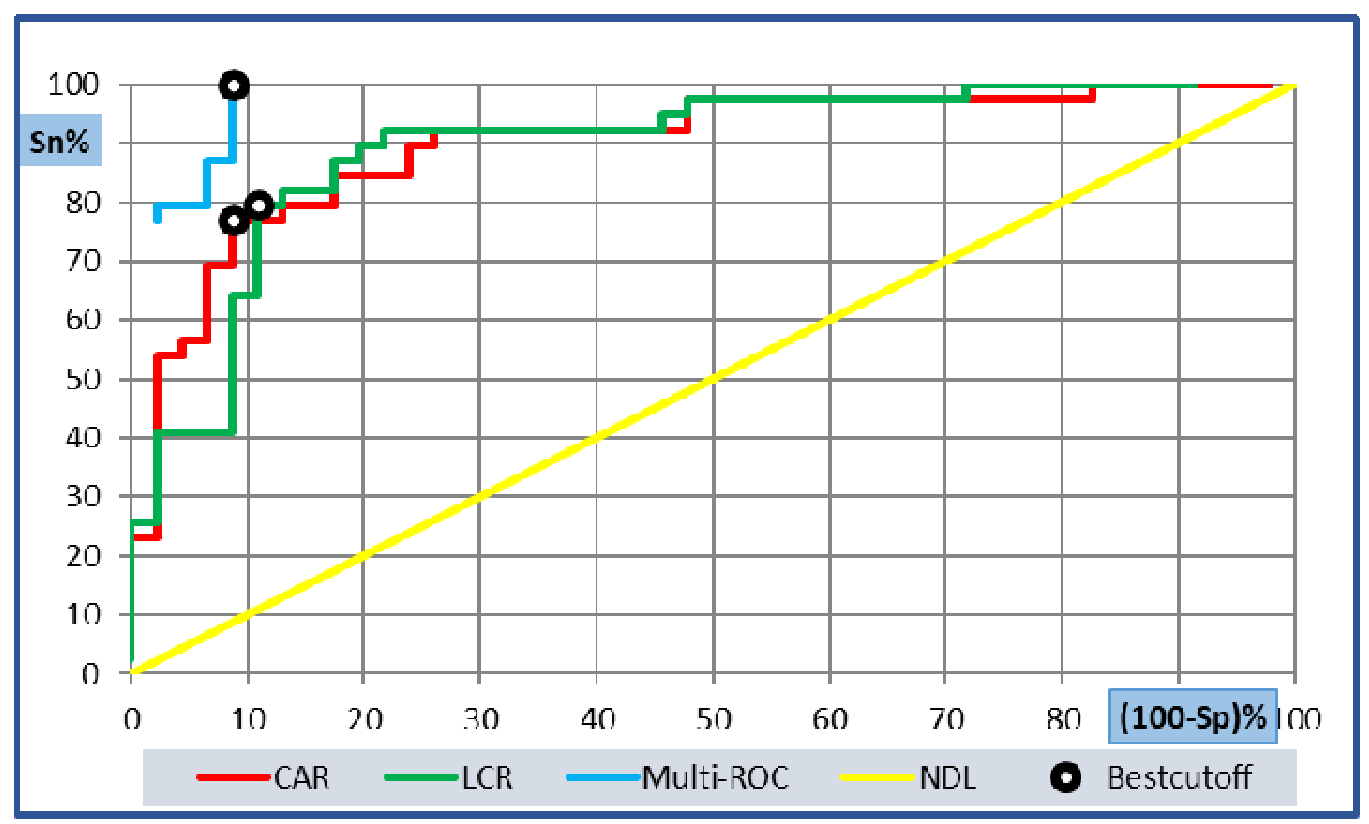

Figure 1: Diagnostic performance of CRP/alb (AUC:0.878; 95\%CI: 0.805-0.952); L/CRP (AUC: 0.873 ; 95\%CI: $0.798-0.948$ ) and their combination (AUC: 0.922 ) for discriminating severe COVID-19 patients from those non-severe. 


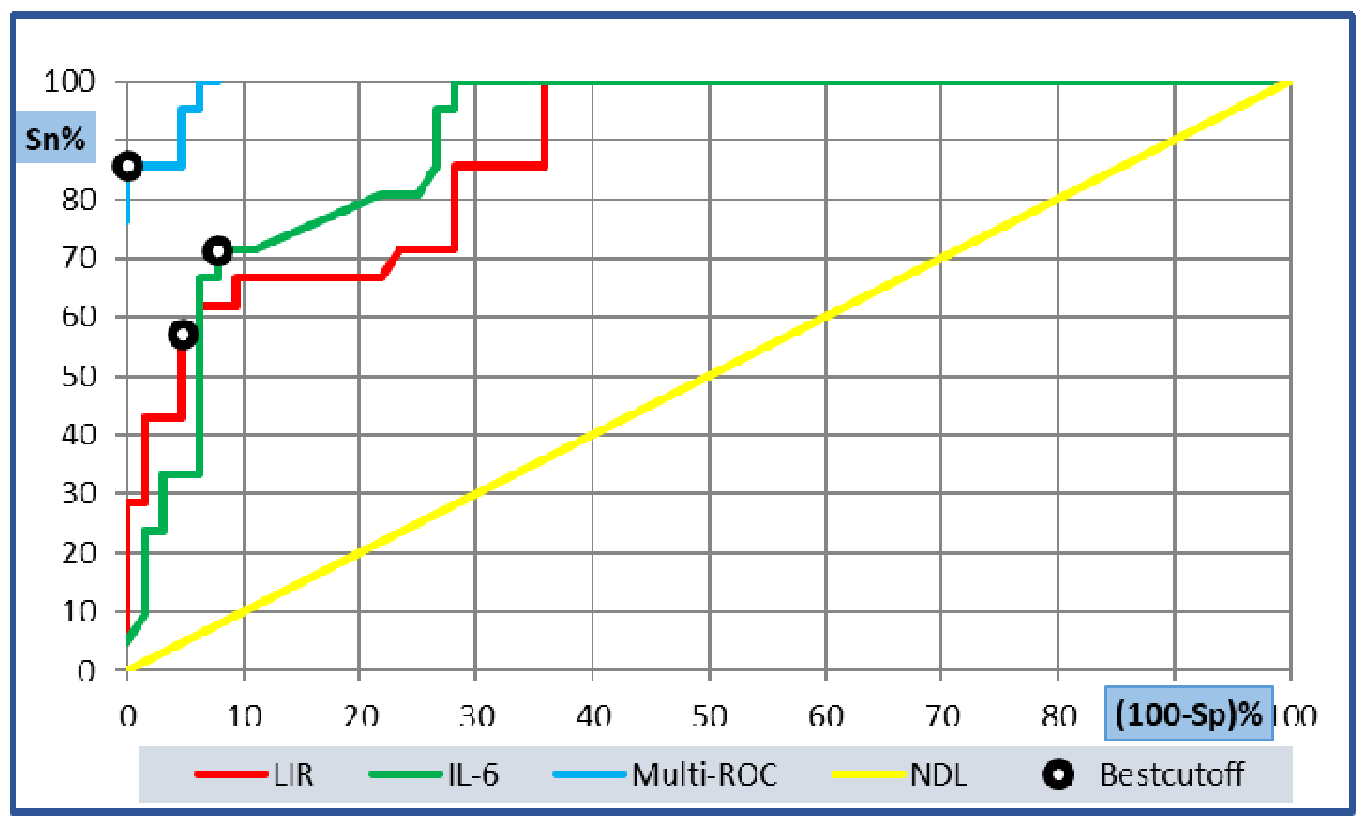

Figure 2: Diagnostic performance of L/IL-6 (AUC: 0.866; 95CI: 0.762-0.970); IL-6(AUC: 0.888; 95CI: 0.819-0.957), and their combination (AUC: 0.946) for discriminating survivors from non-survivors in COVID-19. 
Table 1: Baseline characteristics and laboratory findings of the studied population $(n=85)$.

\begin{tabular}{|ccc|}
\hline & Variable & All Cases \\
$(\mathbf{n}=\mathbf{8 5})$
\end{tabular}

CKD: Chronic kidney disease; CLD: Chronic liver disease; COPD: Chronic obstructive pulmonary disease; DM: Diabetes mellitus; HTN: Hypertension; ICU: Intensive care unit; IHD: Ischemic heart disease; IQR: interquartile range. 
medRxiv preprint doi: https://doi.org/10.1101/2021.06.28.21259644; this version posted November 5, 2021. The copyright holder for this preprint (which was not certified by peer review) is the author/funder, who has granted medRxiv a license to display the preprint in perpetuity. It is made available under a CC-BY-NC-ND 4.0 International license.

Table 2: Comparisons of baseline characteristics and laboratory findings according to COVID-

19 severity and in-hospital mortality.

\begin{tabular}{|c|c|c|c|c|c|c|c|}
\hline \multicolumn{2}{|c|}{ Variable } & \multirow{2}{*}{$\begin{array}{c}\begin{array}{c}\text { Non- severe } \\
(\mathbf{n}=46)\end{array} \\
55.5(41.5-63)\end{array}$} & \multirow{2}{*}{$\begin{array}{c}\begin{array}{c}\text { Severe } \\
(\mathbf{n}=39)\end{array} \\
55(43-67)\end{array}$} & \multirow{2}{*}{$\begin{array}{c}\text { p- value } \\
0.250\end{array}$} & \multirow{2}{*}{$\begin{array}{c}\begin{array}{c}\text { Survivors } \\
(\mathbf{n}=\mathbf{6 4})\end{array} \\
55.5(42-64.75)\end{array}$} & \multirow{2}{*}{$\begin{array}{c}\begin{array}{c}\text { Non- } \\
\text { survivors } \\
(\mathbf{n}=21)\end{array} \\
55(47-69.5)\end{array}$} & \multirow{2}{*}{$\begin{array}{c}\text { p- value } \\
0.454\end{array}$} \\
\hline $\begin{array}{c}\text { Age } \\
\text { (years) }\end{array}$ & $\begin{array}{l}\text { Median } \\
(\mathrm{IQR})\end{array}$ & & & & & & \\
\hline $\operatorname{Sex} n,(\%)$ & $\begin{array}{c}\text { Male } \\
\text { Female }\end{array}$ & $\begin{array}{l}23(50.0 \%) \\
23(50.0 \%)\end{array}$ & $\begin{array}{l}25(64.1 \%) \\
14(35.9 \%)\end{array}$ & 0.191 & $\begin{array}{l}34(53.1 \%) \\
30(46.9 \%)\end{array}$ & $\begin{array}{l}14(66.7 \%) \\
7(33.3 \%)\end{array}$ & 0.277 \\
\hline $\begin{array}{c}\text { Comorbidities n, } \\
(\%)\end{array}$ & $\begin{array}{c}\text { DM } \\
\text { HTN } \\
\text { COPD } \\
\text { IHD } \\
\text { CLD } \\
\text { CKD }\end{array}$ & $\begin{array}{c}13(28.3 \%) \\
15(32.6 \%) \\
2(4.3 \%) \\
0(0.0 \%) \\
2(4.3 \%) \\
4(8.7 \%)\end{array}$ & $\begin{array}{c}18(46.2 \%) \\
19(48.7 \%) \\
5(12.8 \%) \\
5(12.8 \%) \\
1(2.6 \%) \\
11(28.2 \%)\end{array}$ & $\begin{array}{l}0.088 \\
0.131 \\
0.157 \\
0.012 \\
0.657 \\
0.019\end{array}$ & $\begin{array}{c}19(29.7 \%) \\
22(34.4 \%) \\
3(4.7 \%) \\
3(4.7 \%) \\
3(4.7 \%) \\
10(15.6 \%)\end{array}$ & $\begin{array}{c}12(57.1 \%) \\
12(57.1 \%) \\
4(19.0 \%) \\
2(9.5 \%) \\
0(0.0 \%) \\
5(23.8 \%)\end{array}$ & $\begin{array}{l}0.023 \\
0.065 \\
0.038 \\
0.414 \\
0.312 \\
0.393\end{array}$ \\
\hline \multirow{6}{*}{$\begin{array}{c}\text { Laboratory } \\
\text { parameters } \\
\text { Median } \\
\text { (IQR) }\end{array}$} & $\begin{array}{c}\text { Lymp } \\
\times 10^{3} / \mathrm{cmm} \\
\text { CRP }(\mathrm{mg} / \mathrm{L})\end{array}$ & $\begin{array}{c}1.49 \\
(1-2.22) \\
12 \\
(6.5-32)\end{array}$ & $\begin{array}{c}0.9 \\
(0.5-2.2) \\
129) \\
(50-152\end{array}$ & 0.028 & $\begin{array}{c}1.4 \\
(0.77-2.2) \\
18 \\
(7.7-65.75)\end{array}$ & $\begin{array}{c}0.9 \\
(0.55-1.96) \\
152 \\
(57.8-152)\end{array}$ & $\leq 0.001$ \\
\hline & $\begin{array}{l}\text { Albumin } \\
(\mathrm{g} / \mathrm{dl})\end{array}$ & $\begin{array}{c}4 \\
(3.1-4.8)\end{array}$ & $\begin{array}{c}3.2 \\
(2.9-3.6)\end{array}$ & $\leq 0.001$ & $\begin{array}{c}3.75 \\
(3.02-4.35)\end{array}$ & $\begin{array}{c}3 \\
(2.75-3.6)\end{array}$ & 0.001 \\
\hline & $\begin{array}{c}\mathrm{IL}-6 \\
(\mathrm{pg} / \mathrm{ml})\end{array}$ & $\begin{array}{c}32 \\
(18-50)\end{array}$ & $\begin{array}{c}120 \\
(80-220)\end{array}$ & $\leq 0.001$ & $\begin{array}{c}45 \\
(20-97.5)\end{array}$ & $\begin{array}{c}168 \\
(110-275)\end{array}$ & $\leq 0.001$ \\
\hline & L/IL-6 & $\begin{array}{c}40.83 \\
(25.20-98.71)\end{array}$ & $\begin{array}{c}8.33 \\
(4.20-14.54)\end{array}$ & $\leq 0.001$ & $\begin{array}{c}29.55 \\
(11.90-79)\end{array}$ & $\begin{array}{c}5.33 \\
(3.34-14.55)\end{array}$ & $\leq 0.001$ \\
\hline & $\mathrm{CRP} / \mathrm{alb}$ & $\begin{array}{c}0.35 \\
(0.15-0.64)\end{array}$ & $\begin{array}{c}3.87 \\
(1.66-4.90)\end{array}$ & $\leq 0.001$ & $\begin{array}{c}0.52 \\
(0.20-1.70)\end{array}$ & $\begin{array}{c}4.3 \\
(1.82-5.52)\end{array}$ & $\leq 0.001$ \\
\hline & L/CRP & $\begin{array}{c}1211.96 \\
(449.82-2500)\end{array}$ & $\begin{array}{c}105.26 \\
(56.96-230.26)\end{array}$ & $\leq 0.001$ & $\begin{array}{c}703.27 \\
(186.18-2005.35)\end{array}$ & $\begin{array}{c}105.26 \\
(43.56-212.5)\end{array}$ & $\leq 0.001$ \\
\hline $\begin{array}{c}\text { ICU admission } \\
\text { n, }(\%)\end{array}$ & $\begin{array}{l}\text { Positive } \\
\text { Negative }\end{array}$ & $\begin{array}{l}9(19.6 \%) \\
37(80.4 \%)\end{array}$ & $\begin{array}{l}24(61.5 \%) \\
15(38.5 \%)\end{array}$ & $\leq 0.001$ & $\begin{array}{l}17(26.6 \%) \\
47(73.4 \%)\end{array}$ & $\begin{array}{c}16(76.2 \%) \\
5(23.8 \%)\end{array}$ & $\leq 0.001$ \\
\hline $\begin{array}{l}\text { Hospital stay } \\
\text { (days) }\end{array}$ & $\begin{array}{l}\text { Median } \\
\text { (IQR) }\end{array}$ & $10.5(6.75-17.5)$ & $9(5-14)$ & 0.112 & $9.5(6-17)$ & $10(7-16)$ & 0.759 \\
\hline Fate & $\begin{array}{c}\text { Discharged } \\
\text { Died }\end{array}$ & $\begin{array}{c}43(67.2 \%) \\
3(14.3 \%)\end{array}$ & $\begin{array}{l}21(32.8 \%) \\
18(85.7 \%)\end{array}$ & $\leq 0.001$ & & & \\
\hline
\end{tabular}

CKD: Chronic kidney disease; CLD: Chronic liver disease; COPD: Chronic obstructive

pulmonary disease; DM: Diabetes mellitus; HTN: Hypertension; ICU: Intensive care unit; IHD:

Ischemic heart disease; IQR: Interquartile range; Lymp: Lymphocytes. Statistical significance set at 0.05 . 
medRxiv preprint doi: https://doi.org/10.1101/2021.06.28.21259644; this version posted November 5, 2021. The copyright holder for this preprint (which was not certified by peer review) is the author/funder, who has granted medRxiv a license to display the preprint in perpetuity.

It is made available under a CC-BY-NC-ND 4.0 International license .

Table 3: Diagnostic validity and receiver operating curve (ROC) analysis for the ability of CRP, IL-6 and their derived indices to distinguish COVID-19 infected patients according to severity and mortality of the disease

\begin{tabular}{|c|c|c|c|c|c|c|c|}
\hline Indicators & Cut off & AUC & $\begin{array}{c}\text { Specificity } \\
\%\end{array}$ & $\begin{array}{c}\text { Sensitivity } \\
\%\end{array}$ & $\begin{array}{c}\text { NPV } \\
\%\end{array}$ & $\begin{array}{c}\text { PPV } \\
\%\end{array}$ & $\begin{array}{c}\text { Accuracy } \\
\%\end{array}$ \\
\hline \multicolumn{8}{|c|}{ Severity } \\
\hline CRP & 48 & 0.861 & 84.8 & 79.5 & 83.0 & 81.6 & 82.4 \\
\hline IL-6 & 50 & 0.873 & 78.3 & 87.2 & 87.8 & 77.3 & 82.4 \\
\hline L/IL-6 & 11.66 & 0.883 & 95.7 & 71.8 & 80.0 & 93.3 & 84.7 \\
\hline CRP/alb & 1.65 & 0.878 & 91.3 & 76.9 & 82.4 & 88.2 & 84.7 \\
\hline L/CRP & 260.86 & 0.873 & 89.1 & 79.5 & 83.7 & 86.1 & 84.7 \\
\hline $\begin{array}{c}\text { CRP/alb at } \\
1.65+ \\
\mathrm{L} / \mathrm{CRP} \\
\text { at:2300 }\end{array}$ & -- & 0.922 & 91.3 & 100.0 & 100.0 & 90.7 & 95.3 \\
\hline \multicolumn{8}{|c|}{ In- hospital mortality } \\
\hline CRP & 151 & 0.801 & 92.2 & 57.1 & 86.8 & 70.6 & 83.5 \\
\hline IL- 6 & 120 & 0.888 & 92.2 & 71.4 & 90.8 & 75.0 & 87.1 \\
\hline L/IL-6 & 5.40 & 0.866 & 95.3 & 57.1 & 87.1 & 80.0 & 85.9 \\
\hline CRP/alb & 4.21 & 0.812 & 90.6 & 57.1 & 86.6 & 66.7 & 82.4 \\
\hline L/CRP & 129.03 & 0.787 & 79.7 & 61.9 & 86.4 & 50.0 & 75.3 \\
\hline $\begin{array}{c}\text { IL-6 at } \\
120 \mathrm{pg} / \mathrm{ml} \\
+\mathrm{L} / \mathrm{IL}-6 \\
\text { at: } 8\end{array}$ & -- & 0.946 & 100.0 & 85.7 & 95.5 & 100.0 & 96.5 \\
\hline
\end{tabular}

AUC: area under curve; CRP/alb $=C R P(\mathrm{mg} / \mathrm{dl}) /$ albumin $(\mathrm{g} / \mathrm{dl})$; $C R P$ : $C$-reactive protein in $\mathrm{mg} / \mathrm{L} ; \mathrm{IL}-6$ :

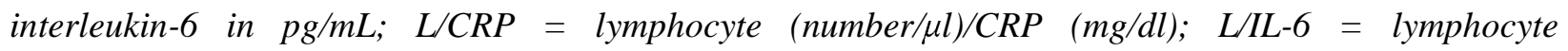
(number/ul)/IL-6 (pg/ml); NPV: negative predictive value; PPV: positive predictive value. 
Table 4: Predictors of COVID-19 progression

\begin{tabular}{|c|c|c|c|c|c|c|c|c|}
\hline \multirow[t]{3}{*}{ Indicator } & \multicolumn{4}{|c|}{ Uni-variate } & \multicolumn{4}{|c|}{ Multi-variate } \\
\hline & \multirow{2}{*}{ P-value } & \multirow{2}{*}{$\begin{array}{l}\text { Odds } \\
\text { ratio }\end{array}$} & \multicolumn{2}{|c|}{$95 \%$ C.I. for $O R$} & \multirow[t]{2}{*}{ P-value } & \multirow{2}{*}{$\begin{array}{l}\text { Odds } \\
\text { ratio }\end{array}$} & \multicolumn{2}{|c|}{$95 \%$ C.I. for OR } \\
\hline & & & Lower & Upper & & & Lower & Upper \\
\hline \multicolumn{9}{|c|}{ Mortality } \\
\hline L/IL-6 & 0.001 & 0.872 & 0.803 & 0.947 & 0.374 & 0.92 & 0.766 & 1.105 \\
\hline CRP/alb & $\leq 0.001$ & 1.921 & 1.431 & 2.579 & 0.439 & 2.602 & 0.231 & 29.268 \\
\hline L/CRP & 0.065 & 0.999 & 0.999 & 1 & 0.164 & 1 & 1 & 1.001 \\
\hline $\mathrm{CRP}(\mathrm{mg} / \mathrm{L})$ & $\leq 0.001$ & 1.021 & 1.011 & 1.031 & 0.758 & 0.988 & 0.917 & 1.065 \\
\hline IL- $6(\mathrm{pg} / \mathrm{ml})$ & $\leq 0.001$ & 1.019 & 1.01 & 1.028 & 0.152 & 1.013 & 0.995 & 1.032 \\
\hline \multicolumn{9}{|c|}{ Severity } \\
\hline L/IL-6 & 0.001 & 0.945 & 0.914 & 0.976 & 0.652 & 1.006 & 0.981 & 1.032 \\
\hline CRP/alb & $\leq 0.001$ & 2.787 & 1.821 & 4.264 & 0.371 & 7.401 & 0.092 & 593.008 \\
\hline $\mathrm{L} / \mathrm{CRP}$ & $\leq 0.001$ & 0.997 & 0.996 & 0.999 & 0.285 & 0.999 & 0.996 & 1.001 \\
\hline $\mathrm{CRP}(\mathrm{mg} / \mathrm{L})$ & $\leq \mathbf{0 . 0 0 1}$ & 1.03 & 1.018 & 1.043 & 0.495 & 0.956 & 0.84 & 1.088 \\
\hline IL- $6(\mathrm{pg} / \mathrm{ml})$ & $\leq 0.001$ & 1.032 & 1.018 & 1.047 & 0.037 & 1.033 & 1.002 & 1.066 \\
\hline
\end{tabular}

CI: Confidence interval 